\title{
Polemics of Body Shaming: A Legal Perspective
}

Mohd Ab Malek Md Shah, Sulaiman Mahzan, Mimi Sofiah Ahmad Mustafa, Ida Rahayu Mahat, Nor Aishah Mohd. Ali, Rosilawati Sultan Mohideen

To Link this Article: http://dx.doi.org/10.6007/IJARBSS/v12-i1/12348 DOI:10.6007/IJARBSS/v12-i1/12348

Received: 12 November 2021, Revised: 14 December 2021, Accepted: 03 January 2022

Published Online: 25 January 2022

In-Text Citation: (Shah et al., 2022)

To Cite this Article: Shah, M. A. M. M., Mahzan, S., Mustafa, M. S. A., Mahat, I. R., Ali, N. A. M., \& Mohideen, R. S. (2022). Polemics of Body Shaming: A Legal Perspective. International Journal of Academic Research in Business and Social Sciences, 12(1), 2690-2697.

Copyright: (c) 2022 The Author(s)

Published by Human Resource Management Academic Research Society (www.hrmars.com)

This article is published under the Creative Commons Attribution (CC BY 4.0) license. Anyone may reproduce, distribute, translate and create derivative works of this article (for both commercial and non0-commercial purposes), subject to full attribution to the original publication and authors. The full terms of this license may be seen at: http://creativecommons.org/licences/by/4.0/legalcode

Vol. 12, No. 1, 2022, Pg. $2690-2697$

http://hrmars.com/index.php/pages/detail/IJARBSS

JOURNAL HOMEPAGE

Full Terms \& Conditions of access and use can be found at http://hrmars.com/index.php/pages/detail/publication-ethics 


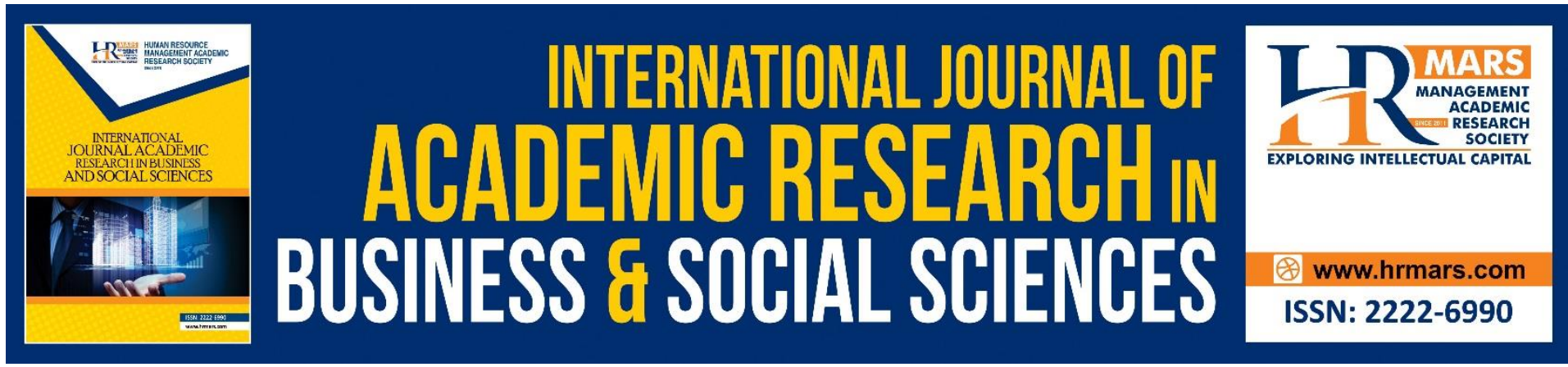

\title{
Polemics of Body Shaming: A Legal Perspective
}

\author{
Mohd Ab Malek Md Shah \\ Department of Law, UiTM Cawangan Melaka, Malaysia
}

Sulaiman Mahzan

Faculty of Computer Science and Mathematics, UiTM Cawangan Melaka, Malaysia

\author{
Mimi Sofiah Ahmad Mustafa, Ida Rahayu Mahat \\ Department of Law, UiTM Cawangan Melaka, Malaysia
}

Nor Aishah Mohd. Ali

Faculty of Accountancy, UiTM Cawangan Melaka, Malaysia

\author{
Rosilawati Sultan Mohideen \\ Faculty of Communication \& Media Studies, UiTM Cawangan Melaka, Malaysia
}

\begin{abstract}
The polemics of body shaming among our society is not a new or isolated issue nowadays. There is various modus operandi adopted by some irresponsible individuals in committing these crimes; including through the increasingly prevalent social media without guilt. In this context, the victim will undergo various negative effects in terms of mental and psychological problems including depression, vindictiveness, irritability, loss of self -confidence, eating disorders and others which in turn can lead to death (because of suicide). Therefore, this study will discuss on the polemics of body shaming in terms of the Malaysian legislative framework from various existing laws which are relevant to be considered to curb this crime from continuing to spread; together with the issues arisen. This is because, there are a handful of people who are less knowledgeable related to this crime of bullying. A qualitative method based on the Document Analysis Method is applied for the research methodology of this study. It is hoped that the findings of the study shall have a contribution for overall benefits of the people towards achieving the 17 Sustainable Development Goals (SDGs) respectively.
\end{abstract} Keywords: Body Shaming, Insult, Legislation, Criminal, Civil

\section{Introduction}

Basically, body shaming refers to mockery or insult to the body (criticism or sarcasm of the body). This situation is also associated with a practice or habit of some people in giving negative comments about one's weight; that is, either directly or indirectly. In fact, the act of body shaming spans religion, race, skin color, gender, social, cultural, and so on. There are various forms of body shaming that have been identified including 'fat shaming' (insulting 
obese physical shape/ weight problems), 'skinny shaming' (body shape problems that are too thin and very popular among women as victims), hair/ hairy body (hair problems that grow excessively and cause feeling uncomfortable), skin color (if having a skin tone that is too dark or pale) and so on.

Body shaming can be interpreted as any act associated with criticizing or criticizing a person's physical shape, size, and appearance (Chaplin, 2005). This act is also associated with forms of verbal violence (verbal violence) or bullying (bullying). In addition, it also refers to acts such as cursing, insulting, and physically abusing a person is a criminal offense that can be prosecuted. This includes all sorts of nasty comments or criticism like "Your skin is too shiny!", "You're too short and ugly!", "You're getting a bowl fuller and looking scarier to others now! You have to exercise regularly to be a little thin" and so on to embarrass or insult a person's physical form either directly or indirectly. The modus operandi for the act of body shaming can be seen in various forms; either physically or social media. There are several methods or mechanisms used by the predator to commit acts of bullying body shaming including 'overt bullying' (direct or overt bullying 'which includes physical and verbal intimidation such as insulting, insulting, giving negative comments, threatening, or threatening with intent to hurt, etc. In addition,' indirect bullying 'which refers to indirect intimidation such as spreading rumors or gossiping about the victim with the aim of damaging the reputation or degrading the victim. In addition, this act of body shaming also involves 'cyberbullying' which is doing virtual intimacy through social media distribution through technology applications including Facebook, Twitter, Instagram and so on.

\section{Literature Review}

\section{Body Shaming from the Malaysian Legislative Perspective}

Communications and Multimedia Act 1998 (Act 588) has two (2) main provisions to are used in acting on content-related matters, namely:

\section{Section 211: Prohibition on provision of offensive content}

No content applications service provider or other person using a content applications service, shall provide content which is indecent, obscene, false, menacing, or offensive in character with intent to annoy, abuse, threaten or harass any person.

A person who contravenes subsection (1) commits an offence and shall, on conviction, be liable to a fine not exceeding RM50,000 or to imprisonment for a term not exceeding one year or to both and shall also be liable to a further fine of RM1,000 for every day or part of a day during which the offence is continued after conviction.

Section 233: Improper use of network facilities or network service, etc.

\section{A person who-}

by means of any network facilities or network service or applications service knowingly-

a. makes, creates, or solicits; and initiates the transmission of, any comment, request, suggestion, or other communication, which is obscene, indecent, false, menacing, or offensive in character with intent to annoy, abuse, threaten or harass another person; or

b. initiates a communication using any applications service, whether continuously, repeatedly, or otherwise, during which communication may or may not ensue, with or without disclosing his identity and with intent to annoy, abuse, threaten or harass any person at any number or electronic address, commits an offence.

A person who knowingly- 
by means of a network service or applications service provides any obscene communication for commercial purposes to any person; or permits a network service or applications service under the person's control to be used for an activity described in paragraph (a), commits an offence.

A person who commits an offence under this section shall, on conviction, be liable to a fine not exceeding RM50,000 or to imprisonment for a term not exceeding one year or to both and shall also be liable to a further fine of RM1,000 for every day during which the offence is continued after conviction.

In relation to this matter, Section 14 of the Minor Offences Act 1955 (Revised 1987) stated that:

14. Any person who uses any indecent, threatening, abusive or insulting words, or behaves in a threatening or insulting manner, or posts up or affixes or exhibits any indecent, threatening, abusive or insulting written paper or drawing with intent to provoke a breach of the peace, or whereby a breach of the peace is likely to be occasioned, shall be liable to a fine not exceeding one hundred ringgit.

Section 509 of the Penal Code 1950 provides that:

Whoever, intending to insult the modesty of any person, utters any word, makes any sound or gesture, or exhibits any object, intending that such word or sound shall be heard, or that such gesture or object shall be seen by such person, or intrudes upon the privacy of such person, shall be punished with imprisonment for a term which may extend to five years or with fine or with both.

\section{Freedom of Speech in the Purview of the Malaysian Legislative Framework}

In essence, freedom of speech is not just about expressing one's personal opinions or ideas without fear or doubt of any possibility or punishment in the future. From another context, the scope of the freedom also covers the field of publication, namely writing, broadcasting, distribution of recordings and oral presentation of ideas. However, we must acknowledge here that there is no absolute freedom on this earth based on the laws that have been provided.

The fact is, rights and freedom of speech are considered among the most important elements of the practice of a democracy; Malaysia is no exception, which adopts a system of parliamentary democracy; in addition to respecting the human rights of every individual through the rule of law. It means, these rights and freedoms can be exercised by every individual if they do not touch on sensitive issues that have been reserved by the Parliament.

\section{The Federal Constitution of Malaysia: An Overview}

As the highest law of the land due to its supremacy, Article 10, in Part II, which touches on fundamental freedoms, clearly states that the rights and freedom of expression (apart from the right to peaceful assembly and association) of every Malaysian citizen are guaranteed by the Federal Constitution as follows;

(1) Subject to Clauses (2), (3) and (4)-

(a) every citizen has the right to freedom of speech and expression;

(b) all citizens have the right to assemble peaceably and without arms;

(c) all citizens have the right to form associations.

(2)Parliament may by law impose- 
(a) on the rights conferred by paragraph (a) of Clause (1), such restrictions as it deems necessary or expedient in the interest of the security of the Federation or any part thereof, friendly relations with other countries, public order or morality and restrictions designed to protect the privileges of Parliament or of any Legislative Assembly or to provide against contempt of court, defamation, or incitement to any offence;

(b) on the right conferred by paragraph (b) of Clause (1), such restrictions as it deems necessary or expedient in the interest of the security of the Federation or any part thereof or public order;

(c) on the right conferred by paragraph (c) of Clause (1), such restrictions as it deems necessary or expedient in the interest of the security of the Federation or any part thereof, public order or morality.

(3) Restrictions on the right to form associations conferred by paragraph (c) of Clause (1) may also be imposed by any law relating to labour or education.

(4) In imposing restrictions in the interest of the security of the Federation or any part thereof or public order under Clause (2) (a), Parliament may pass law prohibiting the questioning of any matter, right, status, position, privilege, sovereignty or prerogative established or protected by the provisions of Part III, Article 152, 153 or 181 otherwise than in relation to the implementation thereof as may be specified in such law.

However, the provisions of the law also stated that the right is subject to Phases (2), (3) and (4); rather than totally or absolutely. In this context, the Federal Constitution has outlined a list of limitations that have been enacted by Parliament including the interests of Federal security or any part thereof, security relations with other countries, public order, protecting the privileges of the Parliament or the State Legislative Assembly (SLA), not intends to insult the institution of the court, defame, and incite to commit an offense. In this context, Parliament is given the authority to implement legislative sanctions in the public interest.

Therefore, the freedom of expression as guaranteed by Article 10 should not be manipulated or exploited as a 'ticket' to be abused by any party with a personal agenda that will ultimately jeopardize political stability and public welfare; particularly pertaining to the reputation and dignity of the individual. In fact, the freedom of speech practiced in Malaysia is not an absolute freedom, otherwise subject to certain legal limitations. Thus, any refusal or violation of all such limitations is punishable; based on the conviction that has been decided by the court.

\section{Defamation Act 1957}

In general, defamation can be defined as an untrue written statement (or speech) that can expose a person to the hatred, ridicule, and contempt of society (Davis, 2002).

On the other hand, defamation is the publication of statements that show a person's reputation and tend to demean a person in the judgment of sane-minded members of society in general or make them shun or avoid it (Saleem \& Sankaran, 2000).

The Defamation Act 1957 is a parent act specifically enacted by Parliament for the purpose of resolving all issues related to libel and slander laws and other malicious falsehoods. There are 2 types of defamation offenses, namely criminal defamation, and civil defamation. For 
criminal defamation, Section 499 of the Penal Code 1950 details that defamation could occur if a statement made by a person will cause the reputation of the deceased to be affected or damaged (if he is still alive; other than having intent to offend a family member or relative who has kinship with the deceased).

The punishment for an offender convicted of an offense is under the provisions of Section 500 of the Penal Code 1950 which is imprisonment for up to two years or a fine.

As for civil defamation, it is based on the Tort Law (tortious liability) which refers to libel and slander. In this context, it refers to any statement disclosed to another person; whether permanent or temporary. As a result, such defamation will damage a person's reputation and good name in the eyes of the public (Salleh Buang, 1992). Such defamation will also create a tendency among members of society to degrade - degrade a person which will eventually cause the victim to prefer to isolate themselves from socializing. In other words, it refers to the publication of a statement (oral or written) that results in a person's reputation falling in the eyes of society.

\section{Research Methodology}

KAEDAH ANALISIS DOKUMEN

Pada amnya, analisis dokumen ialah pecahan kaedah pengumpulan data penyelidikan daripada

analisis kandungan yang merupakan huraian objektif terhadap mesej komunkasi yang dicetak, disiarkan atau digambarkan. Dalam kata lain, bahagian mesej itu dapat didengar, diperoleh dan dilihat dengan merujuk kandungan teks pada perkataan, maksud, gambar, simbol, idea,

\section{Document Analysis Method}

In general, document analysis is a breakdown of research data collection methods from content analysis that is an objective description of a printed, published or illustrated communication message. In other words, parts of the message can be heard, obtained, and seen by referring to the content of the text on words, meanings, pictures, symbols, ideas, themes, or whatever message is communicated. (Marican, 2009: 97; Babbie, 2010: 332).

It is defined as follows:

Document analysis is just what its name implies - the analysis of the written or visual contents of a document. Textbooks, essays, newspapers, novels, magazine articles, cookbooks, political speeches, advertisements, pictures - in fact, the content of virtually any type of written or visual communication can be analyzed in various ways. A person's or group's conscious beliefs, attitudes, values, and ideas are often revealed in the document they produce. (Wallen, 1993: 389).

\section{Findings and Analysis}

Basically, Malaysia is still relatively backward in terms of body shaming laws, including anti cyberbullying, as compared to other more specific and systematic neighboring countries such as Singapore and Indonesia. To this extent, any issues and complaints related to cyber bullying are under the responsibility of the Malaysian Communications and Multimedia Commission (MCMC). Therefore, enforcement actions and the execution of appropriate punishment in accordance with the crime are still vague and weak. 
According to this context, Dr Mazlena Mohamad Husain, a senior lecturer from the Faculty of Law, International Islamic University Malaysia (IIUM) explained that all acts of cyber bullying that ultimately cause the victim to commit suicide are categorized as a crime of cyber bullying whereby the offender shall be penalized under Penal Code 1950. Moreover, she also stated that the cyber bully offender shall be punished under Section 306 under the act which is 'Abetment for the offense of suicide'. However, the validity of the provisions of the clause is considered irrelevant since it does not contain any term 'cyber bullying'.

Apart from that, Roger Chan who is the Chairman of the Human Rights Committee of the Bar Council argued that the scope of 'body shaming' is too broad and not specifically stated in the legal framework in Malaysia. This is because, he argues, there is a wide gap between the terms 'bullying' and 'crime' given that both are exposed to various legal interpretations. Apart from that, he also stated that the act of 'bullying' was related to moral issues and had nothing to do with criminal behavior and did not have any merit to be brought to justice.

Apart from that, the Chairman of the Malaysian Communications and Multimedia Commission (MCMC), Dr. Fadhlullah Suhaimi bin Abdul Malek stated that the victim of body shaming needs to make a police report first before SKMM will provide technical assistance for further action on the evidence that needs to be verified by the police first.

\section{Concluding Remarks}

Every human being craves beauty and craves a perfect body that is God's gift. In fact, is is undoubtedly true that there shall be no human being is willing or willing to be used as an 'object' of jokes or insinuations by the public for 'deficiencies' or 'imperfections' in their respective events. This is related not only to the personal emotions of the individual, but it is an offense that can be punished in legal terms based on the authentic evidence presented in court. Thus, the issue of body shaming or the act of mocking a person's physical form should not be overlooked by society today; let alone to be used as a joke. This is because; it can be classified as a crime given that there are various negative effects that arise against the victim. Proactive and comprehensive action needs to be taken immediately to ensure that this issue is addressed as best as possible, in addition to upholding justice for the victim. This can be done through the strengthening of the existing legal framework; in addition to taking the initiative by enacting acts or statutes specific to this issue for the purpose of mutual benefit; particularly pertaining to the government's efforts towards achieving the 17 Sustainable Development Goals (SDGs) which are related to Peace, Justice and Strong Organizations \& Good Health and Prosperity thoroughly.

\section{Acknowledgement}

This article is part of the findings of the study through the Research Project under the TEJA 2021 Internal Grant Scheme (GDT2021/1-18) UiTM Cawangan Melaka entitled "Mewujudkan Model Kerangka Legislatif yang Spesifik bagi Isu 'Body Shaming' di Malaysia". The researchers would like to extend their special thanks and gratitude to UiTM Cawangan Melaka for the well support and funding this research and the publication respectively.

\section{Corresponding Author}

Mohd Ab Malek bin Md Shah

Department of Law, UiTM Cawangan Melaka, Malaysia, KM. 26, Jalan Lendu, 78000 Alor Gajah, Melaka. 
Email: malek625@uitm.edu.my

\section{References}

Chaplin, J. P. (2005). Kamus Lengkap Psikologi. Jakarta: Rajawali Press. Communications and Multimedia Act 1998 (Act 588).

Davis, P. A. (2002). The Defamation of Choice-of-Law in Cyberspace: Countering the View that the Restatement (Second) of Conflict of Laws is Inadequate to Navigate the Borderless Reaches of the Intangible Frontier. Federal Communications Law Journal, 54 (2), 339363.

Fraenkel, Jack, R., \& Wallen, N. E. (1993). How To design and Evaluate Research in Education. Fraenkel, J. R. \& Wallen, N. E. (1993). How to design and Evaluate Research in Education. New York: McGraw-Hill.

Gam, R. T., Singh, S. K., Manar, M., Kar, S. K., \& Gupta, A. (2020). Body shaming among school going adolescents: prevalence and predictors. International Journal of Community Medicine and Public Health, 7(4), 1324.

Kebebasan Bersuara di Malaysia. (2021). https://ms.wikipedia.org/wiki/Kebebasan_bersuara_di_Malaysia.

Mallow, M. S. (2021). Perlunya akta semua jenis gangguan. https://www.sinarharian.com.my/article/124928/KHAS/Pendapat/Perlunya-aktasemua-jenis-gangguan. Retrieved from Sinar Harian.

Shah, M., Mahzan, S., Sadikan, N. S., Shahudin, M., \& Johari, N. (2021). POLEMIK 'BODY SHAMING' DI MALAYSIA: SUATU ANALISIS AWAL. International Journal of Social Science Research, 3(1), 67-74. Retrieved from https://myjms.mohe.gov.my/index.php/ijssr/article/view/12818. Penal Code 1950.

Marican, S. (2005). Kaedah Penyelidikan Sains Sosial. Petaling Jaya, Selangor: Pearson Prentice Hall.

Buang, S. (1992). Law of Defamation in Malaysia and Singapore. Kuala Lumpur: Central Law Book Company. (OCoLC)608854760.

Faruqi, S. S., \& Ramanathan, S. (2000). Undang-undang dan Peraturan Media di Malaysia. Asian Media Information and Communication Centre (AMIC): Singapura.

Haran, W. S. (2020). Mangsa terdedah kepada depresi bunuh diri. https://www.sinarharian.com.my/article/73970/LAPORAN-KHAS/Mangsa-terdedahkepada-depresi-bunuh-diri. Retrieved from Sinar Harian. 